\title{
How Family Forest Owners Consider Timber Harvesting, Land Sale, and Conservation Easement Decisions: Insights from Massachusetts, USA
}

\author{
Zhao $\mathrm{Ma}^{1}$ and David B. Kittredge ${ }^{2}$ \\ ${ }^{1}$ Department of Environment and Society, Utah State University, 5215 Old Main Hill, Logan, UT 84322-5215, USA \\ ${ }^{2}$ Department of Environmental Conservation, University of Massachusetts Amherst, 160 Holdsworth Way, Amherst, \\ MA 01003-9285, USA
}

Correspondence should be addressed to David B. Kittredge, dbk@eco.umass.edu

Received 16 May 2011; Accepted 23 June 2011

Academic Editor: Frank Gilliam

Copyright ( 2011 Z. Ma and D. B. Kittredge. This is an open access article distributed under the Creative Commons Attribution License, which permits unrestricted use, distribution, and reproduction in any medium, provided the original work is properly cited.

Ten million family forest owners own 35 percent of US forestland. Although one owner's action may be insignificant, many owners' decisions across the landscape and over time can together affect the forest ecosystem. By analyzing survey data from Massachusetts, this paper examines the thought processes of family forest owners when considering timber harvesting, land sale, and conservation easement decisions, all having great potential to shape the future of individual properties and forest landscape. Some factors (e.g., attitudes towards forestland and desire for and experience of cooperation) were important for engaged and unengaged owners, some factors (e.g., attained education level, age, and absenteeism) were irrelevant, and some factors (e.g., acreage and information sources) had mixed effects depending on the decision and landowner engagement level. The results suggest the need to avoid any one-size-fits-all approach, differentiate landowners based on their engagement level, and tailor outreach efforts to address the interests and concerns of particular audiences.

\section{Introduction}

Family forest owners, defined as families, individuals, trusts, estates, family partnerships, and other unincorporated groups of individuals that own forestland [1], control significant forest resources in many countries. Ten million family forest owners own about 35\% of forestland in the US [1]. Most of them hold relatively small tracts of land; however, these small tracts collectively provide important public benefits, including wood fiber, recreation opportunities, and various ecosystem services (e.g., carbon sequestration, watershed protection, and biodiversity conservation). Although an individual owner's action may not significantly affect the forest ecosystem, many owners' decisions across the landscape and over time may together shape the future of the nation's forests and the public benefits they provide. Considering the large number of family forest owners in the US and the importance of their independent and uncoordinated actions, three questions arise: (1) What are the major land management and conservation decisions facing them? (2) Do different family forest owners think about different decisions? (3) What are the factors influencing their consideration? This paper uses survey data from Massachusetts to examine and compare decisions considered by different family forest owners and factors affecting their thought processes.

\section{The Focus on Three Decisions: Timber Harvesting, Land Sale, and Conservation Easement}

American family forest owners constantly face numerous decisions regarding the use and conservation of their land: whether and where to put a hiking trail, whether to pick nontimber forest products, whether to deny public access to the land, whether and where to plant new trees, whether to 
prune or thin the stand, whether to join a government costshare program, whether and where to get information about restoring wildlife habitat, and so on. Among the many issues that family forest owners consider and may eventually act upon, this paper focuses on three specific decisions: whether or not to harvest, whether or not to subdivide and sell part or all of the land, and whether or not to ease the property (sell or donate the development rights associated with the land via a conservation easement program). Some of these decisions (e.g., sale/development of private land and sale or donation of an easement) may be irrelevant in European or Scandinavian countries with differing cultural and political contexts, land use regulations, and strict zoning. Similarly, in other international contexts, even the notion of private ownership is complicated by joint management regimes or community approaches to management and decision making for common pool resources. Landowners in other countries may not face the explicit decisions described in this paper; however, the notions of consideration prior to decision making, proactive versus reactive decision making, and engaged and unengaged landowners are relevant to the future of forests globally.

These three decisions directly affect the future of individual properties and collectively shape the future of forest landscapes, especially in parts of the US with increasing population and development pressure or land use change. For instance, family forest owners may decide to harvest unsustainably and liquidate all timber value. In five or 10 years, they may have to sell a part or all of their property in response to an unexpected need to generate revenue (e.g., to pay for a medical emergency). If landowners sell or donate the development rights associated with their land, their property would be guaranteed to remain forested in perpetuity. However, if no conservation easement is placed on the property and when landowners face an immediate financial need, they might again sell a part or all of their property. There may also be cascading spatial effects, whereby one landowner first liquidates timber value and then subsequently sells land to a developer, which in turn can influence how neighboring landowners view their land and ultimately change the landscape characteristics of the area. Therefore, while it is true that landowners face many decisions on an ongoing basis, this paper focuses on three decisions (timber harvesting, land sale, and conservation easement) because they essentially determine the fate of individual properties and in aggregate the extent of forest landscapes in many parts of the US.

\section{A Need for an Extended Understanding of Landowner Decisions}

The existing literature on the aforementioned three decisions has mostly focused on timber harvesting. For instance, parcel size, stumpage price, and market demand for desirable tree species have been identified as important determinants of family forest owner harvesting behavior [2-5]. Zhang [6] discussed the relationship between regulatory uncertainty and timber harvesting and found that landowners whose forests were close to a known or perceived endangered species habitat tended to have a high propensity to harvest.
Dennis [4] and McDonald et al. [7] suggested that harvesting was influenced by human factors such as a landowner's exogenous income and years of formal education. Vokoun et al. [8] found that the harvesting intensity on private forestlands related to absenteeism and length of ownership. A number of studies from across the country have also suggested ownership objectives as important factors influencing harvesting frequency and intensity on family forestlands [9-14]. In addition, some scholars have discussed the relationship between timber harvesting and landscape factors, including population density [15], household density [16], extent of urbanization [17], and road density [7].

In contrast to the rich understanding of timber harvesting decisions, little empirical work has examined land sale decisions among family forest owners. Some focus group studies have suggested a few factors that may lead family forest owners to consider subdividing and selling a part or all of their land. For instance, some landowners are financially struggling and the cost of maintaining land makes it very tempting to subdivide and sell [18]. High property taxes may also force some owners to first liquidate timber value and then sell land [19]. Intergenerational transfer is another concern. As much as landowners may wish to pass their land to heirs, the next generation may not want the property. Anticipating that his children would sell his land, one man said he planned to sell a block himself [18]. Age also contributes to the consideration of land sale. Some older owners find it increasingly difficult to manage and live on their land; the seclusion they enjoyed before now means it is hard to access shops and other facilities, especially in winter [18]. Losing a spouse and living alone may also contribute to the consideration of selling land [18].

Compared to the sale of land, even less has been done to identify factors affecting conservation easement decisions. One survey was conducted in Virginia to examine the attitudes of nonindustrial private forest owners towards a local conservation easement program. However, 77 percent of respondents were not interested in participating in such program at all [20]. LeVert et al. [21] estimated family forest owners' willingness to sell easements to preserve forestland in Western Massachusetts and Southern Vermont. Their study suggested that policies promoting early development of management plans and cooperation with neighbors appeared to increase the likelihood that landowners would convey an easement. Besides these aforementioned studies, very little evidence has been published that contributes to understanding the conservation easement decision making process of family forest owners.

Although empirical research on land sale and conservation easement decisions is very limited, many studies of landowner behavior in other contexts have identified factors that may be important for understanding how landowners consider selling land or the associated development rights. Research has shown that landowner management and conservation behavior has been influenced by size of land holding, land tenure, residence, personal values, economic considerations, past behavior, future plans, and advice or information received as well as various sociodemographic factors [22]. For instance, landowners with larger acreage 
are more likely to participate in forestry education [23] and endangered species protection programs [24]. How long someone has owned land and whether they live on it have been shown to be positively correlated with forest management decisions [8]. Many studies have suggested that family forest owners value the natural beauty, privacy, and other nonconsumptive amenities of their land and financial gain is generally not a primary reason for owning forestland $[1,9-14,25]$. This may be another key to help understand landowner behavior. Research has also shown that previous experience with forest management is expected to positively affect active management behavior and participation in forest stewardship programs [26]. Age is considered an influential factor in predicting participation in conservation programs; however, it is arguable whether the impact is positive or negative [27, 28]. The effect of landowner occupation on forest management and conservation behavior has been generally undetermined. Some believed that agriculture or forestry-related occupations may increase the likelihood of conservation $[26,28]$, while others suggested otherwise [27]. In addition, the information exchange between natural resource management professionals and landowners is important in determining whether landowners would adopt certain stewardship practices [29]. For instance, Kilgore et al. [30] found that landowners tended to trust forest certification information from a forest landowner association but not a government organization.

Thus far, the existing literature has explored, to a great extent, the various factors affecting timber harvesting as well as factors that may be important for understanding landowner participation in a number of conservation programs. However, little is known about how landowners consider land sale and conservation easement decisions, which, along with timber harvesting, have significant potential to influence the future of forest landscapes.

\section{The Focus on the Consideration of Timber Harvesting, Land Sale, and Conservation Easement}

Both common sense and research suggest that landowners do not make timber harvesting, land sale, and conservation easement decisions often. In fact, landowners may only make such decisions once during the length of their ownership. When landowners do make such decisions, their decisions can be reactive to an immediate financial need, in which case the urgency of the situation may prevent landowners from gathering sufficient information and result in illinformed decisions. Landowners' decisions can also be proactive and made on the basis of full consideration of a suite of alternatives. The goal of a few well-established forestry extension programs across the country, such as the one in Massachusetts, is to minimize the extent to which landowners behave in the reactive way and enable them to carefully consider their management and conservation options even though an actual decision may not follow immediately and may only occur in the future. The challenge is how to achieve such a goal.
A major focus of many existing extension programs is to promote the adoption of forest management plans. These plans have traditionally focused on active management. However, most American family forest owners value natural beauty, privacy, and other amenities of their land and are generally not interested in active management as professionals would define it $[1,11-13,31]$. Therefore, these landowners may not connect the achievement of their often vaguely defined amenity objectives with the need for a forest management plan [32], which is attested by the fact that only four percent of family forest owners throughout the US have adopted such plans [1]. Consequently, there is a great need for better understanding how landowners, without the assistance of such plans, consider various decisions, and what can be done to make high-quality information and assistance available and accessible to these landowners when they need them.

Studies have also shown that only a small segment of American family forest owners are susceptible to traditional messages of "good" forestry promoted for decades through programs such as Tree Farm and Forest Stewardship [32]. This small segment of highly engaged owners are the ones who have been working with forestry professionals, are members of landowner associations, have participated in various extension events, and know where to find information if needed [18]. While maintaining communication with these engaged owners, efforts are needed to connect with those less engaged or completely unengaged owners and understand whether and how they consider various land management and conservation options [25, 32, 33]. Such efforts will help them operate in a proactive decision-making framework or at least be more prepared to act when an immediate financial need emerges.

Because no individual landowners make timber harvesting, land sale, and conservation easement decisions on a regular basis, the need to better understand the thought process of landowners before they finally make a decision becomes greater, particularly considering the limited adoption of forest management plans and the large number of unengaged landowners. Therefore, this paper focuses on examining and comparing factors affecting the consideration of timber harvesting, land sale, and conservation easement decisions among both engaged and unengaged family forest owners regardless of the actual decision outcome. While stopping short of being an actual decision, consideration is a behavioral intention and precursor to making a decision [34]. When landowners consider a decision, they often have already made up their mind at an unconscious level even though they consciously report being undecided [35]. Thus, the focus on identifying factors affecting the consideration of the three decisions will help inform the development of policies and programs to assist family forest owners in better evaluating their management and conservation options and make deliberative decisions on the basis of full consideration at the end of often long and complex thought processes. 
TABLE 1: Description and summary of survey items measuring professed attitudes towards forestland along with principal component analysis summary statistics.

\begin{tabular}{|c|c|c|c|}
\hline $\begin{array}{l}\text { Professed attitudes towards } \\
\text { forestland survey items* }\end{array}$ & Mean (Std. Dev.) & $\begin{array}{l}\text { Rotated principal } \\
\text { component loading } \\
\text { PC 1: GREEN }\end{array}$ & Cronbach's Alpha \\
\hline $\begin{array}{l}\text { I would be pleased if a rare } \\
\text { or threatened species was } \\
\text { found on my land. }\end{array}$ & $3.32(1.33)$ & 0.71 & \multirow{4}{*}{0.80} \\
\hline $\begin{array}{l}\text { What I do on my land } \\
\text { affects others. }\end{array}$ & $3.73(1.05)$ & 0.75 & \\
\hline $\begin{array}{l}\text { My land provides benefits } \\
\text { for society. }\end{array}$ & $3.83(0.94)$ & 0.74 & \\
\hline $\begin{array}{l}\text { My land should provide for } \\
\text { the needs of future plant } \\
\text { and animal populations. }\end{array}$ & $4.03(0.89)$ & 0.84 & \\
\hline $\begin{array}{l}\text { I have a responsibility to } \\
\text { leave my land in at least as } \\
\text { good a condition as I found } \\
\text { it. }\end{array}$ & $4.31(0.76)$ & 0.74 & \multirow{4}{*}{$\begin{array}{l}\text { Retained as unique } \\
\text { variable }\end{array}$} \\
\hline $\begin{array}{l}\text { Land must provide a return } \\
\text { to cover the expenses } \\
\text { associated with ownership. }\end{array}$ & $2.97(1.18)$ & -0.32 & \\
\hline Eigenvalue & & 2.98 & \\
\hline Variance explained & & 0.50 & \\
\hline
\end{tabular}

* Item scale: 1 = strongly disagree, 5 = strongly agree.

\section{Methods}

The data used in this paper were drawn from a mail survey of family forest owners conducted in 2006 in the Deerfield, Westfield, and Millers Rivers watersheds in western Massachusetts. This area spans 4,400 square kilometers and 54 towns, is roughly $78 \%$ forested, and is dominated by family forest ownership. The area is roughly 100 kilometers west of the Boston metropolitan area, 280 kilometers northeast of New York City, and largely rural in nature (e.g., 79\% forested by land use). A simple random sample of 1,200 family forest owners who own 10 or more acres of land was selected from local tax records and surveyed. The survey was administered following Dillman [36] with a final response rate of 46 percent. Data were collected concerning ownership characteristics, reasons for owning forestland, professed attitudes towards forestland, and recalled considerations of land management and conservation options. A telephone survey of nonrespondents was conducted to check for a nonresponse bias. Although similar in most respects, respondents had bigger parcels than nonrespondents and were more likely to have a forest management plan. Therefore, caution should be used when interpreting and extrapolating the results.

All respondents were segmented into two groups according to their level of engagement with their land. The first group is engaged owners, who were enrolled in the current use property tax program, had a forest management plan, were members of the American Tree Farm System, or worked with a consulting forester, indicating that these landowners were highly committed to active management. The rest of the respondents form the second group of unengaged owners.
This paper examines and compares how both engaged and unengaged owners considered timber harvesting, land sale, and conservation easement decisions.

Principal component analysis (PCA) was conducted to consolidate several highly correlated survey items into fewer, uncorrelated factors. PCA is a statistical technique that transforms correlated variables to a smaller set of uncorrelated, composite variables called principal components (PCs) with a minimal loss of information [37]. PCA involves calculating the eigenvalue decomposition of a data covariance matrix [38]. The results of a PCA are usually discussed in terms of PC loadings. A PC loading represents the correlation between the survey item and the PC and is used to define and name each PC. Absolute PC loadings greater than 0.50 are considered significant and indicate a strong association among survey items used to generate that particular PC $[37,39]$. Those items that do not load significantly on derived PCs are often left to stand alone in later analyses.

In this study, PCA was performed separately to three groups of survey items. The first group relates to professed attitudes towards forestland. There were six original items in the questionnaire with high correlations among several of them, indicating a need for data reduction. One PC had an eigenvalue greater than one and also allowed for practical interpretation of its meaning. Table 1 displays the PC loadings. Based on the associated item themes, this PC was defined as environmentally and socially responsible attitudes towards forestland, represented by variable GREEN, which accounted for $50 \%$ of the total variance. The Cronbach's Alpha associated with this PC met the suggested minimum of $0.70[40,41]$, indicating high scale reliability. One variable 
TABLE 2: Description and summary of survey items measuring the importance of information sources in landowner decision making along with principal component analysis summary statistics.

\begin{tabular}{|c|c|c|c|}
\hline $\begin{array}{l}\text { Importance of information sources in } \\
\text { landowner decision making survey items* }\end{array}$ & Mean (Std. Dev.) & $\begin{array}{c}\text { Rotated principal component } \\
\text { loading } \\
\text { PC 1: PROFRES } \\
\end{array}$ & Cronbach's Alpha \\
\hline Advice from a forester or other professional & $3.33(1.16)$ & 0.75 & \multirow{4}{*}{0.80} \\
\hline Consultation of my land management plan & $2.58(1.31)$ & 0.74 & \\
\hline Research from written materials & $2.88(1.12)$ & 0.85 & \\
\hline Online research & $2.39(1.17)$ & 0.80 & \\
\hline My own knowledge and experience & $3.50(1.10)$ & 0.03 & Retained as unique variable \\
\hline Advice from a family member or friend & $2.98(1.21)$ & 0.30 & Retained as unique variable \\
\hline Eigenvalue & & 2.56 & \\
\hline Variance explained & & 0.43 & \\
\hline
\end{tabular}

* Item scale: 1 = not at all important, 5 = extremely important.

did not adequately load on the derived PC and was, therefore, left alone as a unique variable (LANDPAY-land must provide a return to cover the expenses associated with ownership; Table 4).

The survey questionnaire also included six items describing the importance of information sources in landowner decision making. Using PCA, these items were reduced to one PC and two original items (FAMFRI-importance of advice from a family member or friend; OWNEXPimportance of landowner's own knowledge and experience) which did not adequately load on the derived PC (Tables 2 and 4). This PC was defined as the importance of professional advice and research, represented by PROFRES, which accounted for $43 \%$ of the total variance. Cronbach's Alpha associated with this PC met the suggested minimum of 0.70 .

Lastly, PCA was applied to 15 survey items measuring reasons for owning forestland. This procedure effectively reduced the data to two PCs, and two original items (INVEST - financial investment and NATURE-leave land unmanaged and let nature take its course) (Tables 3 and 4). The following names were assigned to these two PCs: PC 1 owning forestland for amenity reasons, represented by AMENITY and PC 2 owning forestland for income and forest products, represented by INCUSE. Combined, AMENITY and INCUSE accounted for $44 \%$ of the total variance. Both PCs had a Cronbach's Alpha of 0.70 or higher, indicating high scale reliability.

An empirical model was developed to estimate the likelihood of considering a decision: DECISION $=\mathrm{f}$ (ACRE, TENURE, ABSENTEE, AGE, EDU, TRAIL, POST, COOP, FAMFRI, PROFRES, OWNEXP, GREEN, LANDPAY, AMENITY, INCUSE, INVEST, and NATURE) (Table 4). DECISION represents three types of decisions: selling timber (DECISIONTIMBER), selling land (DECISIONLAND), and donating or selling a conservation easement (DECISIONCE). The response variable took the value 1 if a landowner considered a particular decision in the last five years, and 0 otherwise. In addition to the aforementioned PCs and remaining individual variables, the empirical model includes eight additional explanatory variables described in Table 4. ACRE is the log of acres of forestland owned by a respondent. TENURE, ABSENTEE, AGE, and EDU are categorical variables described in Table 4 . Both POST and TRAIL are binary, taking the value 1 if a respondent considered posting his/her land or putting a trail in the past five years, and 0 otherwise. COOP, a binary variable, took the value 1 if a respondent considered cooperation with neighboring landowners or was contacted by a neighbor in the past five years, and 0 otherwise.

To estimate the empirical model, binary logistic regression procedure was adopted. In binary logistic regression, probabilities are assigned to each of the two possible outcomes. For a binary response variable $Y$ and a vector of explanatory variables $\vec{X}$, these probabilities are

$$
\begin{gathered}
P\left(Y_{i}=1\right)=P_{i}=\frac{e^{\beta X_{i}}}{1+e^{\beta X_{i}}}, \\
P\left(Y_{i}=0\right)=1-P_{i}=1-\frac{e^{\beta X_{i}}}{1+e^{\beta X_{i}}}=\frac{1}{1+e^{\beta X_{i}}},
\end{gathered}
$$

where $P_{i}$ represents the probability that a family forest owner considered timber harvesting, land sale, or conservation easement in the past five years, $\beta$ is a vector of regression coefficients, and $\beta X_{i}$ is a standard regression notation representing the right hand side of a regression model. Unlike ordinary least squares (OLSs) regression, the logistic procedure involves estimating the regression parameters by maximizing a likelihood function. The coefficient estimates in a logistic regression do not carry the implication of per unit impact of individual explanatory variables as in the OLS case [24]. To draw such implications, marginal effects for each independent variable were calculated as follows:

$$
\frac{d P_{i}}{d X_{i}}=P_{i}\left(1-P_{i}\right) \beta
$$

However, in this paper, the interpretation of the logistic regression results focuses on the identification of significant explanatory variables and their associated signs. 
TABLE 3: Description and summary of survey items measuring reasons for owning forestland along with principal component analysis summary statistics.

\begin{tabular}{|c|c|c|c|c|}
\hline \multirow{2}{*}{$\begin{array}{l}\text { Reasons for owning } \\
\text { forestland survey items* }\end{array}$} & \multirow{2}{*}{ Mean (Std. Dev.) } & \multicolumn{2}{|c|}{ Rotated principal component loading } & \multirow{2}{*}{ Cronbach's Alpha } \\
\hline & & PC 1: AMENITY & PC 2: INCOMEUSE & \\
\hline Income from timber & $2.10(1.10)$ & -0.02 & 0.74 & \multirow{7}{*}{0.70} \\
\hline Income from agriculture & $1.96(1.19)$ & 0.21 & 0.72 & \\
\hline To obtain firewood & $3.05(1.27)$ & 0.47 & 0.52 & \\
\hline To make maple syrup & $1.82(1.13)$ & 0.35 & 0.55 & \\
\hline Personal recreation & $3.73(1.10)$ & 0.54 & 0.06 & \\
\hline As a place to live & $3.99(1.32)$ & 0.59 & 0.00 & \\
\hline To enjoy the scenery & $4.18(1.11)$ & 0.75 & -0.13 & \\
\hline $\begin{array}{l}\text { To protect land from } \\
\text { development }\end{array}$ & $3.58(1.32)$ & 0.76 & -0.16 & \multirow[t]{6}{*}{0.84} \\
\hline To provide wildlife habitat & $3.94(1.17)$ & 0.76 & -0.17 & \\
\hline To have privacy & $4.24(1.13)$ & 0.71 & -0.16 & \\
\hline To protect the environment & $3.92(1.12)$ & 0.72 & -0.26 & \\
\hline To pass on to my children & $3.53(1.44)$ & 0.51 & 0.16 & \\
\hline $\begin{array}{l}\text { To preserve family and } \\
\text { tradition }\end{array}$ & $3.23(1.50)$ & 0.60 & 0.11 & \\
\hline Financial investment & $2.89(1.27)$ & 0.08 & 0.38 & $\begin{array}{c}\text { Retained as unique } \\
\text { variable }\end{array}$ \\
\hline $\begin{array}{l}\text { To leave land unmanaged, } \\
\text { letting nature take its } \\
\text { course }\end{array}$ & $2.74(1.32)$ & 0.30 & -0.45 & \multirow[t]{3}{*}{$\begin{array}{l}\text { Retained as unique } \\
\text { variable }\end{array}$} \\
\hline Eigenvalue & & 4.46 & 2.19 & \\
\hline Variance explained & & 0.30 & 0.15 & \\
\hline
\end{tabular}

*Item scale: 1 = not at all important, $5=$ extremely important.

\section{Results}

Eighty-five percent of respondents owned 100 acres or less of family forestland and the average ownership size was 65 acres. Nearly three quarters of respondents owned their land for more than 10 years. Seventy-two percent were older than 50, among which a third were over 65 . Sixty percent had a Bachelor's degree or additional education beyond college. Seventy-three percent lived on their lands. Less than four percent of respondents produced more than 10 percent but less than 50 percent of their yearly income from their woodlands over the past five years, and the rest generated less than 10 percent of income from woodlands. Twelve percent of respondents had a professionally developed forest management plan.

Landowners had varying opinions about sources of information and decision making. Sixty percent of respondents considered professional advice and research important or extremely important, which includes advice from a forester or other professional, consultation of the forest management plan, research from written materials, and online research. A third of the respondents considered advice from a family member or friend important or extremely important. Half of the respondents considered their own knowledge and experience important or extremely important.
Responding landowner attitudes leaned strongly in the direction of an environmental interest (Table 1). For example, 64 percent of respondents professed a solely environmental and socially responsible attitude towards forestland. Less than two percent professed a solely utilitarian attitude by believing that land must provide a return to cover the expenses associated with ownership. The remaining third had mixed attitudes towards their land and ownership goals.

As previously detailed, PCA helped identify two major types of reasons for owning forestland: amenity (including personal recreation, a place to live, scenery, passing land on to children, preserving family and tradition, protecting land from development, providing wildlife habitat, privacy, and protecting the environment) and forest income and products (including income from timber, income from agriculture, obtaining firewood, and making maple syrup). Roughly 50 percent of respondents owned forestland solely for amenity reasons. One respondent owned forestland solely for forest income and products, and the remaining half indicated mixed reasons. In addition, two respondents considered financial investment the only important reason for owning forestland and one considered leaving land unmanaged and letting nature take its course as the only important reason.

A majority of respondents (81\%) reported having considered at least one decision (selling timber, selling land, 
TABLE 4: Explanatory variables used in the empirical models for estimating three types of decisions: selling timber (DECISIONTIMBER), selling land (DECISIONLAND), and donating or selling a conservation easement (DECISIONCE).

\begin{tabular}{|c|c|c|}
\hline Variable name & Description & Mean (Std. Dev.) \\
\hline ACRE & Continuous-log of acres of forestland owned & $3.60(0.97)$ \\
\hline TENURE & Ordinal-four categories: 1 if $1-5 \mathrm{yrs}, 2$ if $6-10 \mathrm{yrs}, 3$ if $11-20 \mathrm{yrs}, 4$ if $>20 \mathrm{yrs}$ & $3.12(1.08)$ \\
\hline ABSENTEE & Binary-1 if a respondent was an absentee owner; 0 otherwise & $0.27(0.44)$ \\
\hline AGE & Ordinal-four categories: 1 if $<30 \mathrm{yrs}, 2$ if $30-50 \mathrm{yrs}, 3$ if $51-65 \mathrm{yrs}, 4$ if $>65 \mathrm{yrs}$ & $2.96(0.74)$ \\
\hline EDU & $\begin{array}{l}\text { Ordinal-five categories: } 1 \text { if some high school, } 2 \text { if high school, } 3 \text { if some college, } \\
4 \text { if college graduate, } 5 \text { if beyond college }\end{array}$ & $3.74(1.18)$ \\
\hline TRAIL & $\begin{array}{l}\text { Binary- } 1 \text { if a respondent considered putting a trail through his/her land in the } \\
\text { past five yrs; } 0 \text { otherwise }\end{array}$ & $0.44(0.50)$ \\
\hline POST & $\begin{array}{l}\text { Binary- } 1 \text { if a respondent considered posting land and denying public access in the } \\
\text { past five yrs; } 0 \text { otherwise }\end{array}$ & $0.46(0.50)$ \\
\hline COOP & $\begin{array}{l}\text { Binary- } 1 \text { if a respondent considered cooperation with neighboring landowners or } \\
\text { was contacted by a neighbor in the past five yrs; } 0 \text { otherwise }\end{array}$ & $0.33(0.47)$ \\
\hline PROFRES & $\begin{array}{l}\text { Continuous-higher value indicates higher importance of professional advice and } \\
\text { research in landowner decision making (PC loadings, Table 2) }\end{array}$ & $0.00(1.00)$ \\
\hline OWNEXP & $\begin{array}{l}\text { Ordinal-five categories: higher values indicates higher importance of "own } \\
\text { knowledge and experience" in landowner decision making }\end{array}$ & $3.50(1.11)$ \\
\hline FAMFRI & $\begin{array}{l}\text { Ordinal-five categories: higher values indicates higher importance of "advice from } \\
\text { a family member or friend" in landowner decision making }\end{array}$ & $2.96(1.21)$ \\
\hline GREEN & $\begin{array}{l}\text { Continuous-higher value indicates a stronger environmentally and socially } \\
\text { responsible attitude towards forestland (PC loadings, Table 1) }\end{array}$ & $0.00(1.00)$ \\
\hline LANDPAY & $\begin{array}{l}\text { Ordinal-five categories: } 1 \text { if strongly disagree with the statement "land must } \\
\text { provide a return to cover the expenses associated with ownership," } 2 \text { if disagree, } 3 \\
\text { if neutral, } 4 \text { if agree, } 5 \text { if strongly agree }\end{array}$ & $2.98(1.18)$ \\
\hline AMENITY & $\begin{array}{l}\text { Continuous-higher value indicates amenity-oriented reasons for owning forest- } \\
\text { land (PC loadings, Table } 3 \text { ) }\end{array}$ & $0.00(1.00)$ \\
\hline INCUSE & $\begin{array}{l}\text { Continuous-higher value indicates forest income and products-oriented reasons } \\
\text { for owning forestland (PC loadings, Table } 3 \text { ) }\end{array}$ & $0.00(1.00)$ \\
\hline INVEST & $\begin{array}{l}\text { Ordinal-five categories: higher values indicates higher importance of financial } \\
\text { investment as a reason for owning forestland }\end{array}$ & $2.87(1.28)$ \\
\hline NATURE & $\begin{array}{l}\text { Ordinal-five categories: higher values indicates higher importance of leaving land } \\
\text { unmanaged and letting nature take its course as a reason for owning forestland }\end{array}$ & $2.75(1.32)$ \\
\hline
\end{tabular}

and selling or donating a conservation easement) in the past five years. More respondents considered decisions regarding timber (67 percent) than land sale (39 percent) or easement (32 percent; Table 5). Forty-two percent of respondents considered more than one type of decision since owning their properties.

According to the two-group segmentation, 39 percent of respondents were engaged owners and the remaining were unengaged. Almost 80 percent of engaged owners considered selling timber in the past five years, while a significantly lower percentage (roughly 59 percent) of unengaged owners had similar considerations (Table 5). Thirty four percent of engaged owners and 42 percent of unengaged owners considered the sale of land; however, the difference among the two groups was not statistically significant. Finally, approximately 40 percent of engaged owners considered donating or selling a conservation easement, while a significantly lower percentage of unengaged owners (25 percent) had thought about it.

In order to detect multicollinearity among explanatory variables in the empirical model for estimating family forest owners' consideration of three decisions, correlation was calculated between each pair of explanatory variables. Pairwise correlations ranged from -0.4182 to 0.4166 . Variance inflation factor (VIF) was also calculated for each regression, and all VIF values were smaller than 10 . The commonly given rule of thumb for detecting multicollinearity is that pairwise correlations of 0.5 or higher and VIFs of 10 or higher may be reason for concern [42]. Therefore, both analyses indicated no multicollinearity adversely affecting the regression estimates. The results of the logistic regressions are reported for both engaged and unengaged respondents in Table 6.

The log likelihood tests of the empirical model for estimating the consideration of selling timber among engaged and unengaged respondents were both significant $(P<0.01)$ (Table 6). For engaged landowners, significant explanatory variables included AGE, PROFRES, and AMENITY. All three dummy variables of AGE had a negative sign, implying that engaged respondents who were 30 years or older had a lower probability of considering selling timber than those under 30 . However, no statistically significant difference was 
TABLE 5: Consideration of selling timber, selling land, or selling or donating a conservation easement in the past five years by engagement level.

\begin{tabular}{lccc}
\hline & Selling timber & Selling land & Selling or donating a conservation easement \\
\hline All respondents & $66.7 \%$ & $38.7 \%$ & $31.9 \%$ \\
Engaged owners & $79.0 \%$ & $33.7 \%$ & $42.7 \%$ \\
Unengaged owners & $58.6 \%$ & $41.8 \%$ & $25.3 \%$ \\
$t$ statistics & $4.5523^{* * *}$ & -1.7228 & $3.8848^{* * *}$ \\
\hline
\end{tabular}

Note: ${ }^{* *} P<0.05,{ }^{* * *} P<0.01$.

observed among respondents in the three age categories over 30. PROFRES had a positive sign, implying that engaged respondents who viewed professional advice and research as an important source of information were more likely to consider selling timber. AMENITY had a negative sign, suggesting that engaged respondents who owned forestland for amenity reasons were less likely to consider selling timber. The association between education level and consideration of timber sale was unclear. The coefficients on the four dummy variables of EDU suggested that more educated individuals tended to be more likely to consider selling timber, but only two of the coefficients were statistically significant. A different set of significant explanatory variables were identified for estimating unengaged owners' consideration of timber sale, including ACRE, TRAIL, and INCUSE. The coefficients of all three variables were positive, suggesting that unengaged respondents with larger acreage, having recently considered putting a trail through their land, or owning land for forest income and products were more likely to consider selling timber. Again, the association between education level and consideration of timber sale was unclear, suggested by the coefficients on the four dummy variables of EDU.

The log likelihood tests of the empirical model of the consideration of selling land were significant for both engaged and unengaged respondents $(P<0.01$; Table 6). Significant explanatory variables in the engaged owner model included AGE, LANDPAY, and INVEST. All three dummy variables of AGE had a positive sign, implying that engaged respondents who were 30 years or older had a higher probability of considering selling land than those under 30 . However, no statistically significant difference was observed among the three age categories over 30. The coefficients on LANDPAY and INVEST were both positive, suggesting that respondents who believed land must provide a return to cover the expenses associated with ownership or viewed financial investment as an important reason for owning forestland were more likely to consider selling land than those who thought otherwise. The association between the length of ownership and consideration of land sale was unclear, suggested by the fact that only one coefficient on the three dummy variables of TENURE was statistically significant. Interestingly, LANDPAY and INVEST were also significant in the unengaged owner model. Both had a positive sign, implying that unengaged respondents who believed land must pay for itself or owned land as a financial investment were more likely to consider selling land. In contrast, AMENITY was significant with a negative sign, suggesting that unengaged owners who owned land for amenity reasons were less likely to consider selling land.

Lastly, the log likelihood tests of the empirical model for estimating the consideration of conservation easement among engaged and unengaged respondents were both significant $(P<0.05$; Table 6$)$. For engaged owners, significant explanatory variables included ACRE, AGE, and COOP. ACRE had a positive sign, suggesting that those owning more land were more likely to consider an easement. The coefficients on the three dummy variables of AGE had negative signs, suggesting that engaged respondents who were 30 years or older were less likely to consider selling or donating the development rights associated with their land than those under 30. However, no statistically significant difference was observed among the three age categories over 30 . COOP had a positive sign, suggesting that engaged owners who recently considered cooperation with neighboring landowners or were contacted by a neighbor were more likely to consider conveying an easement. The same applies to the unengaged respondents. Those with desire for or experience of cooperating with neighbors were more likely to consider an easement. Additional significant explanatory variables in the unengaged owner model included AGE, TRAIL, and GREEN. The coefficients on the three dummy variables of AGE had positive signs, suggesting that unengaged respondents who were 30 years or older were more likely to think about conservation easement than those under 30 although no statistically significant difference was observed among the three age groups over 30. The coefficient of TRAIL was positive, implying that unengaged respondents having recently considered putting a trial through their land were more likely to consider conveying an easement. GREEN also had a positive sign, suggesting that unengaged respondents with environmentally and socially responsible attitudes towards forestland were more likely to consider an easement.

\section{Discussion}

Certain factors were important for landowners when considering management and conservation options regardless of their engagement levels. For instance, believing forestland must pay for itself and viewing forestland as a financial investment were both associated with the consideration of land sale among engaged and unengaged respondents. This suggests that forest conservation professionals should differentiate and pay special attention to family forest owners with strong financial orientation, because these landowners 
TABLE 6: Comparison of the explanatory variables and their influence in models estimating family forest owners' considerations of decisions.

\begin{tabular}{|c|c|c|c|c|c|c|}
\hline \multirow[b]{2}{*}{ Explanatory variables } & \multicolumn{3}{|c|}{ Engaged owners } & \multicolumn{3}{|c|}{ Unengaged owners } \\
\hline & Selling timber & Selling land & $\begin{array}{l}\text { Selling or donating } \\
\text { conservation easement }\end{array}$ & Selling timber & Selling land & $\begin{array}{l}\text { Selling or donating } \\
\text { conservation easement }\end{array}$ \\
\hline \multirow{2}{*}{ ACRE } & 0.028 & 0.091 & $0.156^{* *}$ & $0.164^{* * *}$ & -0.028 & -0.009 \\
\hline & $(0.030)$ & $(0.056)$ & $(0.065)$ & $(0.058)$ & $(0.056)$ & $(0.033)$ \\
\hline \multirow{2}{*}{ TENURE: $6-10$ yrs } & -0.057 & $-0.344^{* *}$ & -0.317 & -0.097 & -0.026 & 0.028 \\
\hline & $(0.179)$ & $(0.069)$ & $(0.188)$ & $(0.144)$ & $(0.147)$ & $(0.098)$ \\
\hline \multirow{2}{*}{ TENURE: $11-20$ yrs } & 0.049 & -0.018 & -0.088 & 0.041 & 0.169 & 0.004 \\
\hline & $(0.095)$ & $(0.197)$ & $(0.241)$ & $(0.125)$ & $(0.142)$ & $(0.085)$ \\
\hline \multirow{2}{*}{ TENURE: $>20$ yrs } & 0.056 & -0.140 & -0.233 & 0.190 & 0.229 & 0.070 \\
\hline & $(0.136)$ & $(0.208)$ & $(0.231)$ & $(0.109)$ & $(0.124)$ & $(0.082)$ \\
\hline \multirow{2}{*}{ ABSENTEE } & -0.122 & 0.149 & 0.033 & 0.149 & 0.003 & 0.051 \\
\hline & $(0.109)$ & $(0.135)$ & $(0.143)$ & $(0.089)$ & $(0.099)$ & $(0.065)$ \\
\hline \multirow{2}{*}{ AGE: $30-50$ yrs } & $-0.999 * * *$ & $0.998^{* * *}$ & $-0.996^{* * *}$ & -0.409 & 0.536 & $0.999^{* * *}$ \\
\hline & $(0.001)$ & $(0.002)$ & $(0.003)$ & $(0.314)$ & $(0.305)$ & $(0.001)$ \\
\hline \multirow{2}{*}{ AGE: $51-65$ yrs } & $-0.999^{* * *}$ & $1.000^{* * *}$ & $-1.000^{* * *}$ & -0.377 & 0.510 & $0.998^{* * *}$ \\
\hline & $(0.001)$ & $(0.001)$ & $(0.000)$ & $(0.297)$ & $(0.311)$ & $(0.003)$ \\
\hline \multirow{2}{*}{ AGE: $>65$ yrs } & $-0.998^{* * *}$ & $0.991^{* * *}$ & $-0.982 * * *$ & -0.406 & 0.478 & $0.988^{* * *}$ \\
\hline & $(0.001)$ & $(0.002)$ & $(0.009)$ & $(0.312)$ & $(0.293)$ & $(0.005)$ \\
\hline \multirow{2}{*}{ EDU: high school } & $0.170^{* *}$ & 0.116 & 0.240 & 0.204 & $-0.483^{* *}$ & 0.009 \\
\hline & $(0.062)$ & $(0.528)$ & $(0.349)$ & $(0.195)$ & $(0.122)$ & $(0.193)$ \\
\hline \multirow{2}{*}{ EDU: some college } & 0.113 & 0.184 & 0.174 & 0.379 & -0.486 & 0.018 \\
\hline & $(0.071)$ & $(0.546)$ & $(0.370)$ & $(0.146)$ & $(0.166)$ & $(0.188)$ \\
\hline \multirow{2}{*}{ EDU: college graduate } & $0.225^{* *}$ & 0.170 & 0.313 & 0.341 & -0.470 & 0.039 \\
\hline & $(0.102)$ & $(0.520)$ & $(0.332)$ & $(0.180)$ & $(0.199)$ & $(0.195)$ \\
\hline \multirow{2}{*}{ EDU: beyond college } & 0.353 & 0.015 & 0.450 & $0.445^{* *}$ & -0.460 & 0.050 \\
\hline & $(0.217)$ & $(0.443)$ & $(0.302)$ & $(0.161)$ & $(0.221)$ & $(0.196)$ \\
\hline \multirow{2}{*}{ TRAIL } & 0.127 & -0.039 & 0.037 & $0.243^{* * *}$ & 0.118 & $0.135^{* *}$ \\
\hline & $(0.081)$ & $(0.112)$ & $(0.124)$ & $(0.079)$ & $(0.086)$ & $(0.057)$ \\
\hline \multirow{2}{*}{ POST } & 0.061 & 0.093 & -0.084 & 0.063 & 0.034 & 0.078 \\
\hline & $(0.055)$ & $(0.115)$ & $(0.121)$ & $(0.086)$ & $(0.091)$ & $(0.056)$ \\
\hline \multirow{2}{*}{$\mathrm{COOP}$} & -0.040 & 0.143 & $0.338^{* * *}$ & 0.040 & -0.003 & $0.213^{* * *}$ \\
\hline & $(0.065)$ & $(0.115)$ & $(0.112)$ & $(0.095)$ & $(0.098)$ & $(0.079)$ \\
\hline \multirow{2}{*}{ PROFRES } & $0.082^{* *}$ & 0.024 & 0.030 & -0.003 & 0.036 & 0.022 \\
\hline & $(0.033)$ & $(0.058)$ & $(0.066)$ & $(0.048)$ & $(0.051)$ & $(0.031)$ \\
\hline \multirow{2}{*}{ OWNEXP } & -0.014 & -0.012 & 0.052 & -0.013 & -0.062 & 0.029 \\
\hline & $(0.029)$ & $(0.053)$ & $(0.056)$ & $(0.038)$ & $(0.041)$ & $(0.027)$ \\
\hline \multirow{2}{*}{ FAMFRI } & -0.039 & -0.021 & -0.032 & -0.042 & 0.025 & 0.017 \\
\hline & $(0.028)$ & $(0.048)$ & $(0.055)$ & $(0.040)$ & $(0.041)$ & $(0.026)$ \\
\hline \multirow{2}{*}{ GREEN } & -0.006 & -0.055 & 0.031 & -0.006 & -0.056 & $0.064^{* *}$ \\
\hline & $(0.041)$ & $(0.078)$ & $(0.090)$ & $(0.050)$ & $(0.055)$ & $(0.034)$ \\
\hline LANDPAY & -0.010 & $0.126^{* *}$ & -0.109 & 0.002 & $0.152^{* * *}$ & 0.049 \\
\hline & $(0.027)$ & $(0.053)$ & $(0.059)$ & $(0.042)$ & $(0.046)$ & $(0.028)$ \\
\hline AMFNITY & $-0.083^{* *}$ & $-0.074^{* *}$ & 0.045 & 0.027 & $-0.159^{* * *}$ & -0.013 \\
\hline & $(0.041)$ & $(0.058)$ & $(0.071)$ & $(0.051)$ & $(0.054)$ & $(0.032)$ \\
\hline INCUISF & 0.037 & -0.099 & 0.075 & $0.234^{* * *}$ & -0.086 & -0.031 \\
\hline & $(0.035)$ & $(0.072)$ & $(0.080)$ & $(0.064)$ & $(0.061)$ & $(0.037)$ \\
\hline INVEST & 0.005 & $0.135^{* * *}$ & 0.024 & -0.013 & $0.131^{* * *}$ & -0.011 \\
\hline & $(0.022)$ & $(0.049)$ & $(0.055)$ & $(0.038)$ & $(0.042)$ & $(0.024)$ \\
\hline
\end{tabular}


TABle 6: Continued.

\begin{tabular}{lcccccc}
\hline & & \multicolumn{2}{c}{ Engaged owners } & & \multicolumn{2}{c}{ Unengaged owners } \\
Explanatory variables & Selling timber & Selling land & $\begin{array}{c}\text { Selling or donating } \\
\text { conservation easement }\end{array}$ & Selling timber & Selling land & $\begin{array}{c}\text { Selling or donating } \\
\text { conservation easement }\end{array}$ \\
\hline NATURE & -0.022 & 0.080 & 0.055 & 0.032 & 0.005 & 0.012 \\
\# of observations & $(0.021)$ & $(0.042)$ & $(0.050)$ & $(0.038)$ & $(0.040)$ & $(0.023)$ \\
LR chi-squared & 131 & 129 & 130 & 204 & 206 & 206 \\
Pseudo R & $44.93^{* * *}$ & $55.46^{* * *}$ & $42.43^{* *}$ & $59.37^{* * *}$ & $64.04^{* * *}$ & $44.94^{* * *}$ \\
\hline
\end{tabular}

Note:

(1) Coefficients are marginal effects; standard errors are in parenthesis.

(2) Significant levels are from the logistic regression coefficients; ${ }^{*} P<0.05$; ${ }^{* * *} P<0.01$.

tend to subdivide and sell their land to developers, thereby affecting the forest landscape and associated ecosystem services beyond individual property lines. In the case of conservation easement, cooperation positively contributed to the consideration of this alternative among both engaged and unengaged owners. From a policy perspective, public programs that encourage landowners to cooperate with one another may have a positive impact on promoting easement adoption. Although very few programs exist to foster cooperation among neighbors [43], cross-boundary cooperation among adjacent landowners is important for a variety of conservation programs [44], and research has shown that certain segments of the landowner population are interested in cooperating with neighbors to improve wildlife habitat, protect land, and take other conservation measures [37]. Therefore, it is important to identify these landowners and effectively target them as potential sellers or donors of easements. Also, there is potential for promoting easement programs through outreach efforts that encourage cooperation.

Some factors had different effects on respondents' consideration of management and conservation options. For instance, acreage was associated with the consideration of timber sale among unengaged owners. This result is consistent with previous studies suggesting that size does matter in terms of harvesting behavior. However, it also suggests the importance of differentiating unengaged owners from engaged owners. Particularly, because those unengaged owners may never contact a forestry professional or participate in any extension event, programs that provide technical or financial assistance to encourage sustainable harvesting should identify specific strategies to connect with these unengaged individuals and address their needs and concerns. Interestingly, the result also indicates that engaged owners valued professional advice and research when thinking about timber harvesting, while this source of information was unimportant for unengaged owners. This further suggests the need to identify outreach strategies targeting unengaged individuals other than what has been done traditionally (e.g., forest management plan, workshops, pamphlets, and websites).

Another example illustrating how engaged and unengaged owners differ in their thought processes relates to their attitudes towards forestland. Environmental and social responsibility was important for unengaged respondents considering a conservation easement, but unimportant for engaged respondents. This result again suggests the importance of tailor-designed outreach programs for landowners at different engagement levels. Messages discussing how landowners will enjoy the financial or amenity benefits associated with donating or selling an easement may not be effective among unengaged owners. However, messages highlighting the environmental and social benefits of an easement may attract attention and interest from this group. Specifically, these messages could focus on helping unengaged owners better understand how a conservation easement would help rare or endangered species found on their land, provide benefits to society, and keep land in a good condition for future generations of humans as well as plants and animals.

Absenteeism was not significantly related to the consideration of any of the three decisions regardless of landowner engagement level. This is interesting, because the literature suggests that absentee owners tend to hold higher amenity values for their forest ownership, therefore, are less likely to harvest [8]. One might also assume that absentee owners are less emotionally invested in their land and, hence, more inclined to consider selling land. However, these results suggest that absentee owners were not appreciably different from those who lived on their land in their consideration of timber harvesting, land sale, and conservation easement, when holding other variables constant.

These results also suggest that age did not matter. In a review of empirical economics literature on timber harvesting, reforestation, and stand improvements on family forestlands, Beach et al. [45] found six studies that included age as an explanatory variable in their econometric models. Among these studies, two found that age was insignificant and four found that older landowners were less likely to harvest timber, reforest, or improve stand conditions. Our results further expand the literature by suggesting that among landowners who were 30 years or older, age did not affect their consideration of timber harvesting, nor how they thought about land sale and conservation easement. Particularly, considering that less than three percent of family forest owners in the US are under 35 , age does not seem to matter for most landowners. 
Moreover, conservation easements have been discussed as a viable option of estate planning to help landowners prepare for retirement and/or death, particularly among those who are older [46]. However, this paper suggests that age was not a determinant in the consideration of conservation easement for those over 30 , and there is a need to broaden the potential audience for related outreach. More than a third of family forest owners in the US are 65 years or older [1]. Consequently, a large number of intergenerational land transfers are expected in the next 10 to 20 years. However, different landowners may have different concerns when considering passing land on to their heirs. Some may be worried about protecting the future of their land and more likely to donate or sell an easement, while others may be concerned about issues of equitability and flexibility and reluctant to consider an easement if it would tie the hands of their children. This may explain the lack of statistically significant difference among the three age groups (30-50 yrs, 51-65 yrs, $>65 \mathrm{yrs}$ ) of both engaged and unengaged owners. More efforts are needed to better understand the needs and concerns of landowners who will be considering land transfer decisions in the near future and the opportunities for promoting easements among these landowners.

This paper also suggests that relative income level was not influential in the consideration of income generating actions of selling timber or land. The attained education level was used as a proxy for income, since survey respondents are often reluctant to provide this information. Education had no significant relation to respondents' consideration of timber or land sale decisions. This suggests that respondents from lower income strata were not more likely to consider selling timber or land than more affluent respondents. It further suggests that the consideration of such decisions is probably not triggered by the daily financial need of landowners although less affluent landowners may have fewer alternatives when facing a financial emergency than those from higher income strata. They, therefore, may have to rely on their timber and/or land when specific significant financial need arises.

Finally, it is worth noting that engaged and unengaged owners shared similar interests in land sale and the factors influencing the consideration of the sale of land were also similar across the two groups. It seems that the consideration of such decisions is either philosophical or investmentrelated regardless of landowner engagement level. This poses a great challenge for forest conservation programs. Efforts are needed to identify strategies to work with landowners who believe land must pay for itself and create effective financial incentives to help them sustain their ownership. There is also potential for identifying landowners who own forestland as a financial investment and introducing alternative revenue-generating activities to them (e.g., selling a conservation easement). However, the limitation of these alternatives needs to be recognized. In areas with highly profitable real estate markets, these alternatives may never win compared to the sale of land to a developer.

\section{Conclusions}

Making decisions about one's land, while reactive and largely uninformed by traditional measures (e.g., management plans, professional advice) can, nonetheless, take time. Thus, the temporal lag between "consider a decision" and "make or execute a decision" can be significant. At any point, there can be many owners who are thinking about harvesting timber, selling land, or conveying a conservation easement. This dynamic, ongoing thought process often involves multiple family members, complicated personal values, emotions and opinions, and both immediate and future legal and financial considerations. This paper discusses the potential landscape effects of these three decisions, highlights the importance of understanding how landowners think about these decisions, and identifies various factors affecting their thought processes.

This paper suggested that some factors, such as attitudes towards forestland, were important for both engaged and unengaged owners; some factors, such as attained education level (a proxy for income), were apparently irrelevant, and some factors, such as acreage and information sources, had mixed effects on landowners depending on their engagement levels and the decision in question. Therefore, it is important for conservation professionals, agency officials, and policy makers to avoid any one-size-fits-all approach, differentiate between groups of family forest owners, and tailor each outreach message and forestry program to address the needs and concerns of a particular audience. In order to do so, it is necessary to further investigate the family forest owner decision-making process and not rely on assumptions of landowners acting according to professional advice or their forest management plans.

\section{Acknowledgment}

This research was supported by the National Research Initiative of the USDA Cooperative State Research, Education, and Extension Service (Grant no. 2006-55101-16564).

\section{References}

[1] B. J. Butler, "Family forest owners of the United States," Tech. Rep. NRS-27, USDA Forest Service, Northern Research Station, Newtown Square, Pa, USA, 2006.

[2] C. S. Binkley, Timber Supply from Private Nonindustrial Forests: A Microeconomic Analysis of Landowner Behavior, Yale University School of Forestry and Environmental Studies Bulletin No. 92, Yale University Press, New Haven, Conn, USA, 1981.

[3] P. Catanzaro, D. T. Damery, A. D'Amato, and K. Ferrare, Economic Viability of Ownerships in the Deerfield River Watershed, UMass Extension, Amherst, Mass, USA, 2007.

[4] D. F. Dennis, "An economic analysis of harvest behavior: integrating forest and ownership characteristics," Forest Science, vol. 35, no. 4, pp. 1088-1104, 1989.

[5] D. B. Kittredge, A. O. Finley, and D. R. Foster, "Timber harvesting as ongoing disturbance in a landscape of diverse ownership," Forest Ecology and Management, vol. 180, no. 13, pp. 425-442, 2003. 
[6] D. Zhang, "Endangered species and timber harvesting: the case of red-cockaded woodpeckers," Economic Inquiry, vol. 42, no. 1, pp. 150-165, 2004.

[7] R. I. McDonald, M. S. Bank, J. Burk, D. B. Kittredge, G. Motzkin, and D. R. Foster, "Forest harvesting and land-use conversion over two decades in Massachusetts," Forest Ecology and Management, vol. 227, no. 1-2, pp. 31-41, 2006.

[8] M. Vokoun, G. S. Amacher, and D. N. Wear, "Scale of harvesting by non-industrial private forest landowners," Journal of Forest Economics, vol. 11, no. 4, pp. 223-244, 2006.

[9] T. W. Birch, "Private forestland owners of the United States," Resource Bulletins NE-134, USDA Forest Service, Northeastern Forest Experiment Station, Radnor, Pa, USA, 1996.

[10] B. J. Butler, E. C. Leatherberry, C. Best, M. A. Kilgore, R. N. Sampson, and K. Larson, "America's family forest owners," Journal of Forestry, vol. 102, no. 7, pp. 4-14, 2004.

[11] D. L. Erickson, R. L. Ryan, and R. De Young, "Woodlots in the rural landscape: landowner motivations and management attitudes in a Michigan (USA) case study," Landscape and Urban Planning, vol. 58, no. 2-4, pp. 101-112, 2002.

[12] R. L. Johnson, R. J. Alig, E. Moore, and R. J. Moulton, "NIPF landowners' view of regulation," Journal of Forestry, vol. 95, no. 1, pp. 23-28, 1997.

[13] A. Kendra and R. B. Hull, "Motivations and behaviors of new forest owners in Virginia," Forest Science, vol. 51, no. 2, pp. 142-154, 2005.

[14] J. Kuuluvainen, H. Karppinen, and V. Ovaskainen, "Landowner objectives and nonindustrial private timber supply," Forest Science, vol. 42, no. 3, pp. 300-309, 1996.

[15] D. N. Wear, R. Liu, J. M. Foreman, and R. M. Sheffield, "The effects of population growth on timber management and inventories in Virginia," Forest Ecology and Management, vol. 118, no. 1-3, pp. 107-115, 1999.

[16] J. Liu, G. C. Daily, P. R. Ehrlicht, and G. W. Luck, "Effects of household dynamics on resource consumption and biodiversity," Nature, vol. 421, no. 6922, pp. 530-533, 2003.

[17] I. A. Munn, S. A. Barlow, D. L. Evans, and D. Cleaves, "Urbanization's impact on timber harvesting in the south central United States," Journal of Environmental Management, vol. 64, no. 1, pp. 65-76, 2002.

[18] J. Langer, Family Forest Owners: Insights into Land-Related Stewardship, Values, and Intentions. Report on Focus Group Findings Prepared for the Sustaining Family Forests Initiative, GfK Roper Public Affairs \& Media, New York, NY, USA, 2008.

[19] B. J. Butler, J. H. Hewes, P. Catanzaro et al., "Effects of federal, state, and local tax policies on family forest owners," Tech. Rep. 2010-01, USDA Forest Service/University of Massachusetts Amherst, Family Forest Research Center, Amherst, Mass, USA, 2010.

[20] J. P. Dedrick, T. E. Hall, R. B. Hull, and J. E. Johnson, "The Forest Bank: an experiment in managing fragmented forests," Journal of Forestry, vol. 98, no. 3, pp. 22-25, 2000.

[21] M. J. LeVert, T. H. Stevens, and D. B. Kittredge, "Willingnessto-sell conservation easements: a case study," Journal of Forest Economics, vol. 15, no. 4, pp. 261-275, 2009.

[22] A. Brook, M. Zint, and R. De Young, "Landowners' Responses to an Endangered Species Act Listing and Implications for Encouraging Conservation," Conservation Biology, vol. 17, no. 6, pp. 1638-1649, 2003.

[23] K. A. Blatner and D. M. Baumgartner, "NIPF use of landowner assistance and education programs in Washington State," Western Journal of Applied Forestry, vol. 6, no. 4, pp. 90-94, 1991.
[24] S. Mehmood and D. Zhang, "Determinants of forest landowner participation in the Endangered Species Act Safe Harbor Program," Human Dimension of Wildlife, vol. 10, no. 4, pp. 249-257, 2005.

[25] A. O. Finley and D. B. Kittredge, "Thoreau, Muir, and Jane Doe: different types of private forest owners need different kinds of forest management," Northern Journal of Applied Forestry, vol. 23, no. 1, pp. 27-34, 2006.

[26] C. D. Bell, R. K. Roberts, B. C. English, and W. M. Park, "A logit analysis of participation in Tennessee's forest stewardship program," Journal of Agriculture and Applied Economics, vol. 26, no. 2, pp. 463-472, 1994.

[27] C. Langpap, "Conservation incentives programs for endangered species: an analysis of landowner participation," Land Economics, vol. 80, no. 3, pp. 375-388, 2004.

[28] V. Nagubadi, K. T. McNamara, W. L. Hoover, and W. L. Mills, "Program participation behavior of nonindustrial forest landowners: a probit analysis," Journal of Agriculture and Applied Economics, vol. 28, no. 2, pp. 323-336, 1996.

[29] R. S. Gootee, K. A. Blatner, D. M. Baumgartner, M. S. Carroll, and E. P. Weber, "Choosing what to believe about forests: differences between professional and non-professional evaluative Criteria," Small-Scale Forestry, vol. 9, no. 2, pp. 137$152,2010$.

[30] M. A. Kilgore, J. E. Leahy, C. M. Hibbard, and J. S. Donnay, "Assessing family forestland certification opportunities: a Minnesota case study," Journal of Forestry, vol. 105, no. 1, pp. 27-33, 2007.

[31] S. B. Jones, A. E. Luloff, and J. C. Finley, "Another look at NIPFs: facing our "myths"', Journal of Forestry, vol. 93, no. 9, pp. 41-44, 1995.

[32] D. B. Kittredge, "Extension/outreach implications for America's family forest owners," Journal of Forestry, vol. 102, no. 7, pp. 15-18, 2004.

[33] B. J. Butler, M. Tyrrell, G. Feinberg, S. VanManen, L. Wiseman, and S. Wallinger, "Understanding and reaching family forest owners: lessons from social marketing research," Journal of Forestry, vol. 105, no. 7, pp. 348-357, 2007.

[34] I. Ajzen and M. Fishbein, Understanding Attitudes and Predicting Social Behavior, Prentice Hall, Englewood Cliffs, NJ, USA, 1980.

[35] S. Galdi, L. Arcuri, and B. Gawronski, "Automatic mental associations predict future choices of undecided decisionmakers," Science, vol. 321, no. 5892, pp. 1100-1102, 2008.

[36] D. A. Dillman, Mail and Internet Surveys: The Tailored Design Method, John Wiley \& Sons, New York, NY, USA, 2nd edition, 2000.

[37] A. O. Finley, D. B. Kittredge, T. H. Stevens, C. M. Schweik, and D. C. Dennis, "Interest in cross-boundary cooperation: identification of distinct types of private forest owners," Forest Science, vol. 52, no. 1, pp. 10-22, 2006.

[38] I. Samish, "Search and sampling in structural bioinformatics," in Structural Bioinformatics, J. Gu and P. E. Bourne, Eds., pp. 207-236, John Wiley \& Sons, Hoboken, NJ, USA, 2nd edition, 2009.

[39] J. F. Hair, R. E. Anderson, R. L. Tatham, and W. C. Black, Multivariate Data Analysis, Prentice Hall, Upper Saddle River, NJ, USA, 5th edition, 1998.

[40] L. J. Cronbach, "Coefficient alpha and the internal structure of tests," Psychometrika, vol. 16, no. 3, pp. 297-334, 1951.

[41] J. C. Nunnally, Psychometric Theory, McGraw-Hill, New York, NY, USA, 2nd edition, 1978.

[42] D. N. Gujarati, Basic Econometrics, McGraw-Hill, New York, NY, USA, 3rd edition, 1995. 
[43] S. M. Campbell and D. B. Kittredge, "Ecosystem-based management on multiple NIPF ownerships," Journal of Forestry, vol. 94, no. 2, pp. 24-29, 1996.

[44] M. W. Brunson, "Social dimensions of boundaries: balancing cooperation and self interest," in Stewardship across Boundaries, R. L. Knight and P. B. Landres, Eds., Island Press, Washington, DC, USA, 1998.

[45] R. H. Beach, S. K. Pattanayak, J. C. Yang, B. C. Murray, and R. C. Abt, "Econometric studies of non-industrial private forest management: a review and synthesis," Forest Policy and Economics, vol. 7, no. 3, pp. 261-281, 2005.

[46] W. C. Siegel, H. L. Haney Jr., and J. L. Greene, "Estate planning for forest landowners: what will become of your timberland?" Tech. Rep. SRS-112, USDA Forest Service, Southern Research Station, Asheville, NC, USA, 2009. 

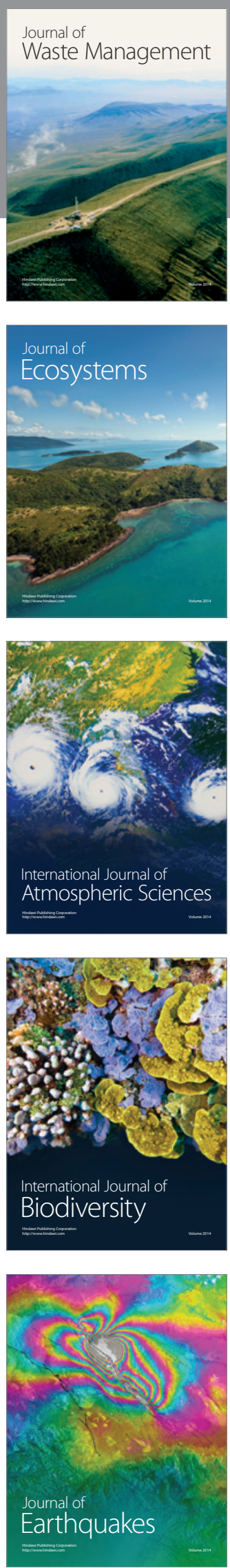
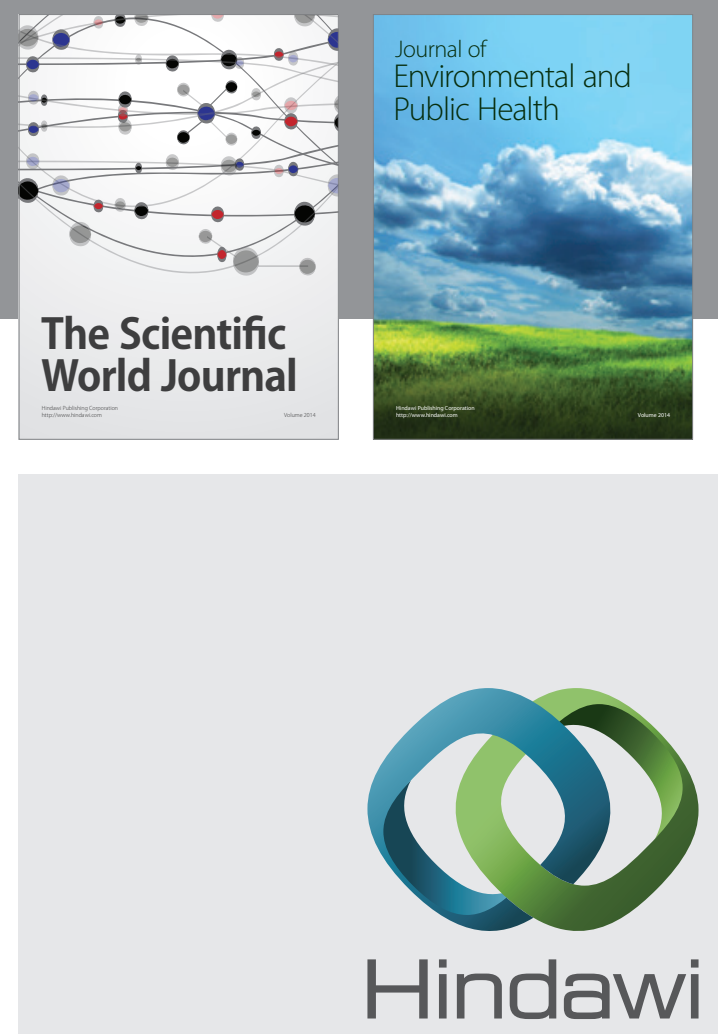

Submit your manuscripts at

http://www.hindawi.com
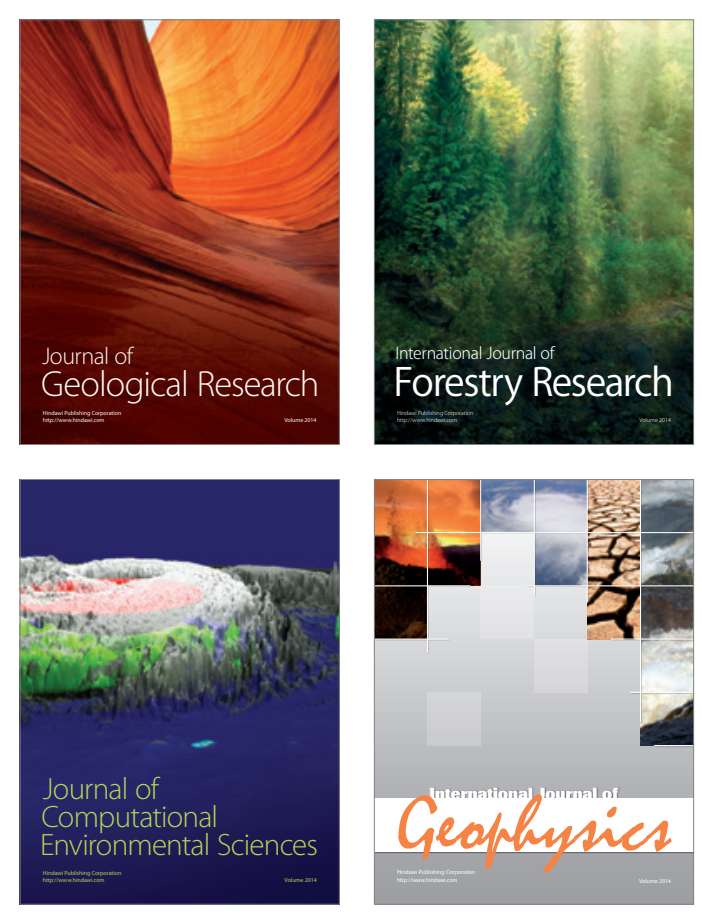
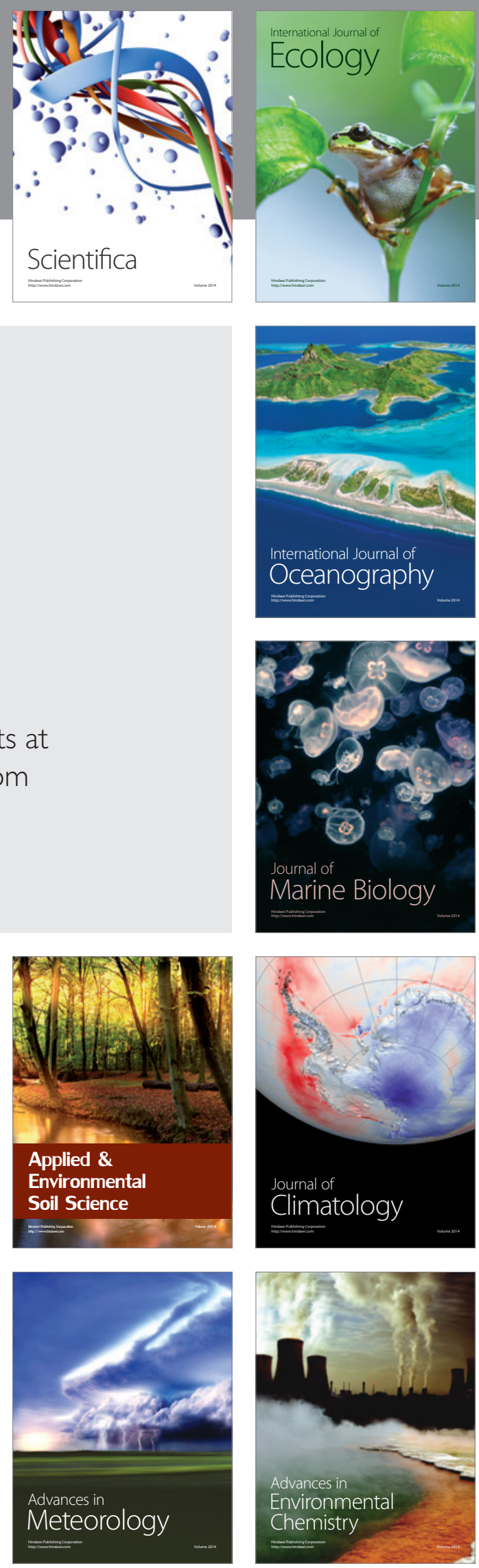